\title{
Dante's Cannibal Count: Unnatural Hunger and its Reckoning
}

\author{
PATRICIA VAZQUEZ
}

$\coprod_{N} 200$ I THE bones of an allegedly cannibalistic Count were removed from a tomb in Pisa to let science determine whether or not Count Ugolino had eaten his children as his last meal, as recounted by Dante in Canto 33 of the Inferno. Dante invites us to peer at the wicked soul of Count Ugolino as an eccentric doctor might beckon us to gawk at a glass jar filled with his strangest medical oddity. Except what is extraordinarily grotesque about Ugolino isn't for the eye to see, it's a deformity of the soul, he's a moral monster. And yet, he wasn't a serial killer, and violent murderers on a scale of evil are not relegated to the bottom of hell, as one might assume. In Dante's architectonic vision of hell, that prize goes to the treacherous, and the traitor par excellence is Count Ugolino. We tend to forget this as we listen with both fascination and horror to Ugolino's entreaties. We consequently, and quite predictably, abandon reason and impartiality by rising up to defend him on the grounds that hunger would drive anyone mad. We often assume Dante errs or dismiss his reasons for assigning Ugolino to the ninth and lowest circle of hell.

Perhaps to put these rumors to rest the descendants of Count Ugolino della Gherardesca graciously gave paleontologist Francesco Mallegni permission to carry out DNA tests on the five skeletons that were buried in a crypt under the family chapel. If the forensic analysis is to be believed, Dante was mistaken. "Even if Ugolino had wanted to eat the flesh of his offspring," Mallegni explained, "he couldn't have because he didn't have any teeth"1 (fig.I). 


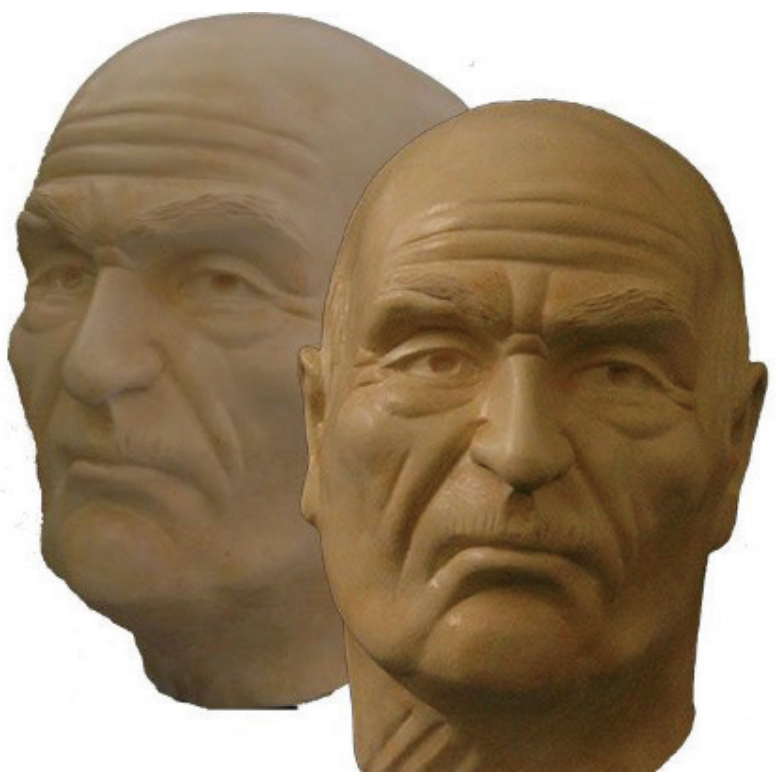

Figure I. "Ugolino della Gherardesca [Forensic facial reconstruction. By permission of Francesco Mallegni] I Che Faccia Avevano I Vip Del Passato-Foto." Il Tirreno. February 03, 20I 5 . Slide 6 of I7. Accessed January 29, 20I9. http://iltirreno.gelocal.it/empoli/foto-e-video/2015/02/03/fotogalleria/che-faccia-avevano-i-vip-del-passato-I.I0793432\#6.

Although Mallegni is 98 per cent certain the genetic tests match Ugolino's living relatives, ${ }^{2}$ that did not stop archivist Paola Benigni from coming forward in 2008 to challenge the findings, claiming the documents used to locate the bones were fascist forgeries. ${ }^{3}$ But the professor of paleontology's tests are compelling. Consider how the mitochondrial DNA (passed down from mother to son) proves the kinship ties between those imprisoned in the Tower. You have an aging grandfather, his two sons, and the clincher, his two grandchildren were "cousins by unrelated mothers and the tests bore that out as well." 4

In clearing the Count of his alleged cannibalism, however, Mallegni's tests have consigned the Count's crimes to the realm of fiction. What's problematic about Mallegni dismiss- 
ing Canto 33 as "a beautiful dramatic verse about a political enemy" is that it implies subterfuge on Dante's part. ${ }^{5}$ As if his disposition towards Ugolino had been colored by his enmity towards the Count, resulting in a portrait that evokes both fear and loathing. "Clearly a scientist and a poet see the world differently," Mallegni explains in an interview, "but it makes for fascinating work to compare the two." 6

What Mallegni concludes after comparing the science with the poetry is that Dante "only insinuates that Ugolino ate his offspring" and that the target of the poet's ire was not in fact the Count but his captors, "I prefer to think of the verses as a magnificent orchestration intended to whip up hatred of the Pisans for killing Ugolino and trying to wipe out his family, too."7 By framing the Count as victim, the imputations against him are minimized or forgotten, which should hardly come as a surprise when you stop to think of it; the Count has seduced others as well.

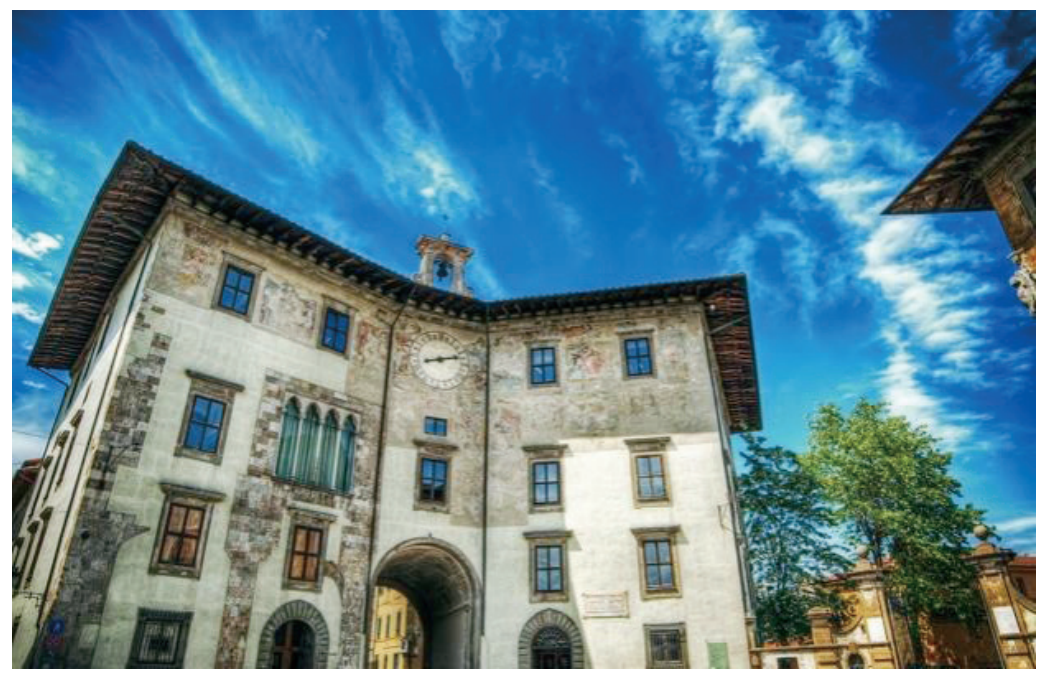

Figure 2. "Torre Dei Gualandi: The 'Other' Tower of Pisa You Shouldn't Miss.” ITALY Magazine. June I 5, 20I6. Accessed January 29, 20I9. https:// www.italymagazine.com/news/torre-dei-gualandi-other-tower-pisa-youshouldnt-miss. 
To make the case that Count Ugolino's placement in hell is justified, that Dante was in fact holding him accountable for sins that exceeded even those evil machinations for which the Count was notorious, we need to return to the scene of the crime, to where Count Ugolino was last seen wasting away with his two sons, Gaddo and Uguccione, and his two grandsons, Brigata and Anselmuccio, while imprisoned in a tower at Pisa-not the Leaning Tower of Pisa where Galileo mesmerized his pupils with experiments involving cannonballs, the other one (fig. 2).

Just north of Piazza dei Cavalieri there is another tower known as the Muda Tower, which used to belong to the Gualandi family. In the year I288, Ugolino and his sons were held captive there, and the man holding the keys, Archbishop Ruggieri, threw them into the Arno, the river that rushes past the city on its way to the sea. When the five prisoners were left to starve, the tower was given a new nickname: Torre della Fame. Fame, the Italian word for hunger, is derived from Latin fames, from which English gets its words for famine and famished. As Ugolino clarifies, "la qual per me ha il titol della fame" ("which is called the tower of hunger, after me"; Inf. 33.23; Musa 37I; fig. 3).

Prue Shaw regards the pathos of Ugolino's predicament as "perhaps the most moving of all the stories told in hell." In her eyes, this is "the story of a father forced to see his children die of hunger, unable to help them or offer comfort in their hour of need." 8

What's odd about Shaw's assessment of Ugolino is that she completely glosses over the Count's cannibalism, focusing instead on his suffering, so that we feel sorry for him. Such pity is woefully misguided. Pitying the damned is a mistake that tempts Dante time and again during his tour of hell, forcing his guide Virgil to rebuke him on numerous occasions:

Qui vive la pietà quando è ben morta

Chi è più scellerato che colui 


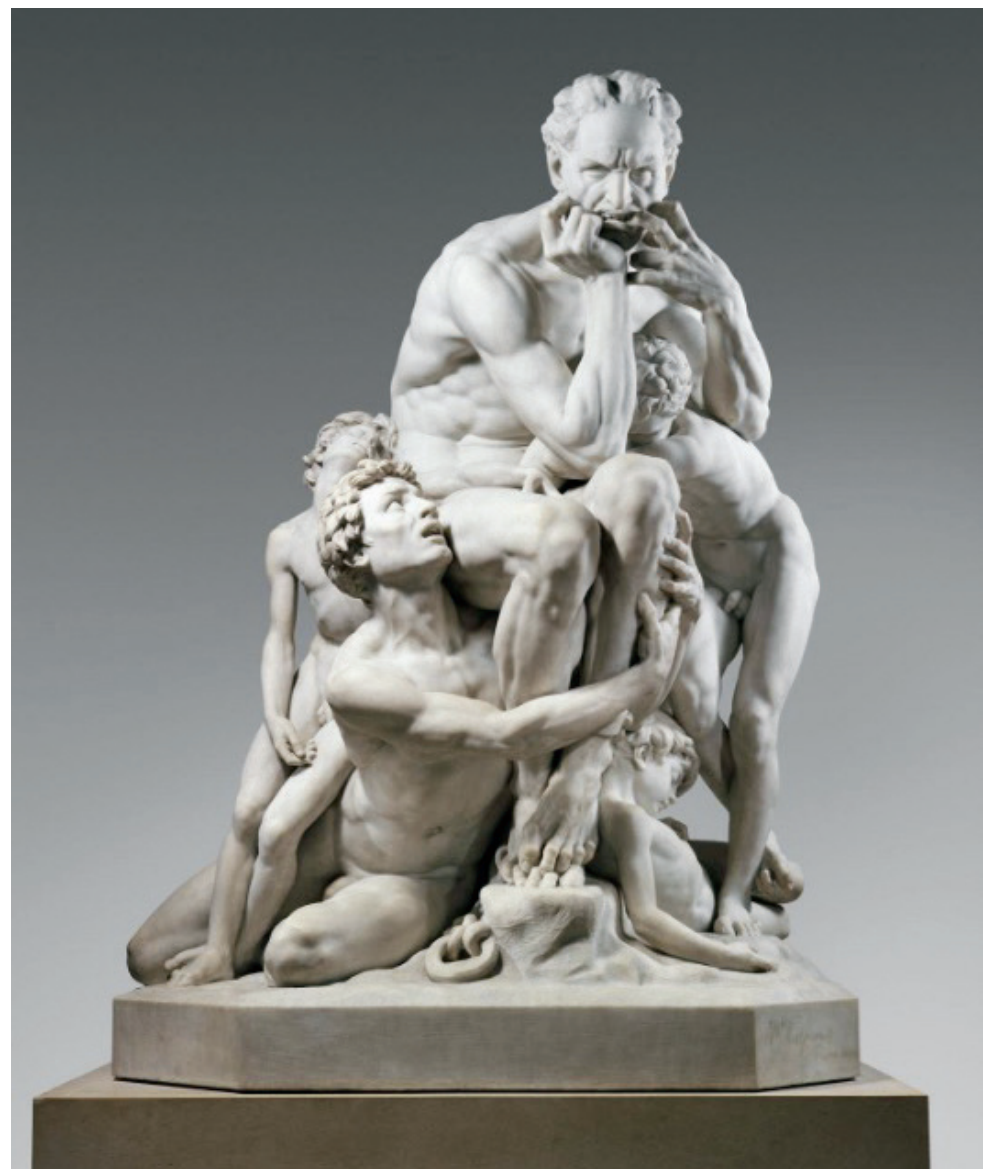

Figure 3. "Ugolino and his sons" by Jean-Baptiste Carpeaux, I865-67, sculpture, The Metropolitan Museum of Art, New York, www.metmuseum.org.

che al giudicio divin passion porta?

$$
\text { (Inf. 20.28-30) }
$$

... There is no place for pity here.

Who is more arrogant

within his soul, who is more impious

than one who dares to sorrow at God's judgment?

(Ciardi I 58 ) 
Giuseppe Mazzotta offers up another tantalizing proposition collected from Borges, which suggests that

Dante wants to leave us in suspension, to believe that it's possible that Ugolino may have eaten the children, but maybe he didn't. I think that Borges is right, that we are not supposed to be able to tell, that the ambiguity of that line is never going to be quite resolved. It's going to remain forever unknowable. ${ }^{9}$

The ambiguous line Mazzotta refers to is that climactic moment when the defeated Count admits, "posocia, più che il dolor, poté il digiuno" ("Then hunger proved more powerful than grief"; Inf. 33.75; Musa 372). Granted, it is possible to infer from this line that the Count starved before his grief could kill him, but the peril of such a reading is that it humanizes him. Robert Hollander rails against this tendency of reading Ugolino in a sympathetic light, reminding us to distance ourselves as we did from Francesca's equally seductive but distorted and self-serving narrative. ${ }^{10}$ Like Francesca, Ugolino implores Dante to pity him but Dante feels pity only for Ugolino's children, whose singular misfortune lay in being related to the Count. Lashing out at the Archbishop, Dante says, "non dovei tu i figliuoi porre a tal croce" ("You had no right to make his children suffer"; 87; Musa 373). However, the suffering to which Ugolino's sons were exposed cannot be said to fall entirely in the lap of the Archbishop, regardless of what Ugolino's self-exculpatory testament would have you believe.

Donna L. Yowell is quick to remind us, lest we forget, that "Bestiality marks Ugolino from the moment we encounter him ..."11 The Count appears in the ninth circle where all those who betrayed family, country, guests, and benefactors are imprisoned in a lake of ice. Why ice? Because it reflects the frigid inner landscape of these cold-hearted souls. As Canto 32 comes to a close, Dante catches sight of two men "due ghiacciati in una buca" ("frozen together in a single 
hole"; I25; Musa 366). The Count is described as a bestial man whose teeth are clamped down on another man's skull, clearly relishing his revenge the way a ravenous dog chews a bone "e come il pan per fame si manduca / cosi il sovran li denti all'altro pose / là 've il cervel s'aggiugne con la nuca" ("As a man with hungry teeth tears into bread,/the soul with capping head had sunk his teeth/into the other's neck, just beneath the skull"; I27-29; Musa 366; fig. 4).

For John Ciardi, this is a picture-perfect illustration of the law of retribution: "in life Ruggieri sinned against Ugolino by denying him food; in Hell he himself becomes the food for his victim." 12 Perhaps, but again we stray, for Ciardi turns Ugolino into an instrument of torture, and by doing so, we pivot towards the crimes and punishment of Ruggieri, the Archbishop of Pisa. What remains a mystery is this: why is the Count being punished alongside the Archbishop who betrayed him? What, exactly, was the Count's crime?

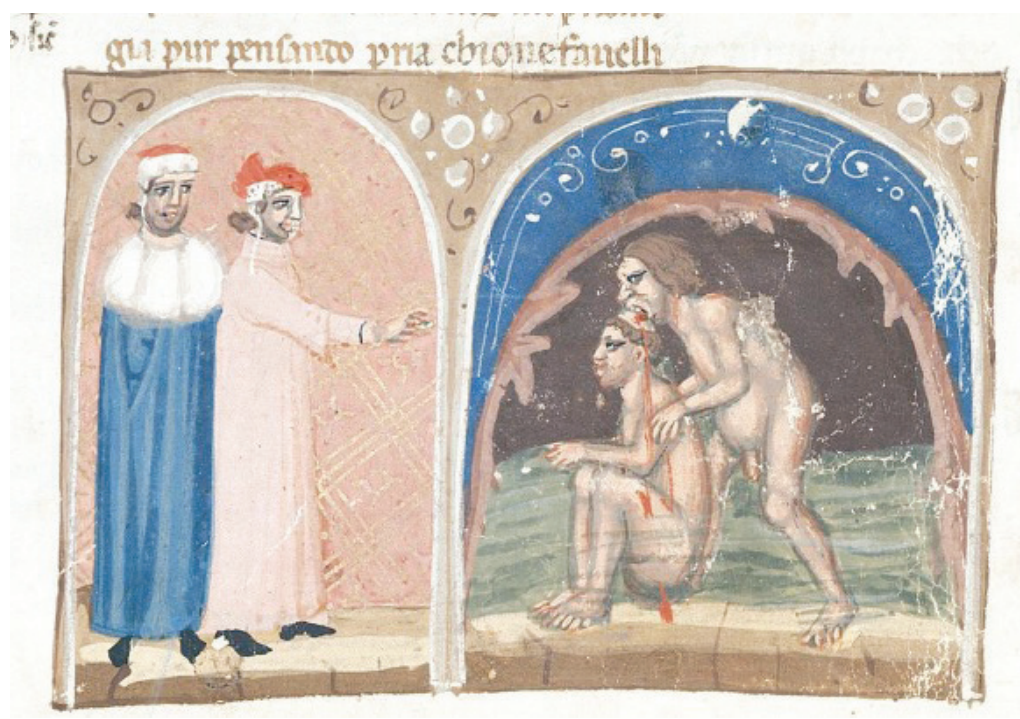

Figure 4. "Count Ugolino gnawing Archbishop Ruggieri’s scalp." Circa I4C, (C) British Library Board, Egerton 943 f. $58 \mathrm{v}$. By Permission of the British Library. 
Conventional wisdom suggests there are two possible justifications. One is that he was disloyal to his hometown of Pisa and the other is that he ate his dead children. To be sure, there is evidence that Ugolino was a backstabbing son-of-a-bitch, but not enough to earn a seat at the table for the worst sinners of all time, in all the Universe. The second, and more controversial of the two, would have us believe that Ugolino is being punished for eating his children after they had taken turns dying in front of him. Under such circumstances, it would be hard to blame him, and as this violates our collective sense of justice, too often and too many end up pitying him.

"We cannot in fact be entirely sure of what particular action Dante has in mind in putting Ugolino here,"13 Teodolinda Barolini confesses. Like others who have studied this canto in earnest, she finds it "implausible that Ugolino's true betrayal from Dante's perspective was the ceding of the castles." ${ }^{14}$ What makes it hard to believe the Count is being punished for giving up three castles is that he did it as a political necessity. As the chief magistrate of Pisa, Ugolino negotiated with hostile neighbors in order to neutralize their threats. Just like Odysseus, when he found himself between a rock and a hard place, chosen to sacrifice a few men in order to save his ship, the Count was forced to sacrifice a few castles to protect the city of Pisa.

What Barolini finds more compelling is the idea that once the Count had become master of the city, he had betrayed his nephew, Nino Visconti. Nino, whose mother was the Count's sister, distinguished himself as a judge with a reputation for showing no mercy to those who accepted bribes. No doubt this earned him Dante's eternal admiration, for we encounter Nino later in Purgatorio, where heavenly salvation although delayed is assured (fig. 5).

In stark contrast to the ever-faithful Nino, Barolini informs us that "Ugolino's career was marked by continuous switching back and forth of party allegiance." 15 Once Nino fell out of favor with his uncle, Count Ugolino had his nephew 


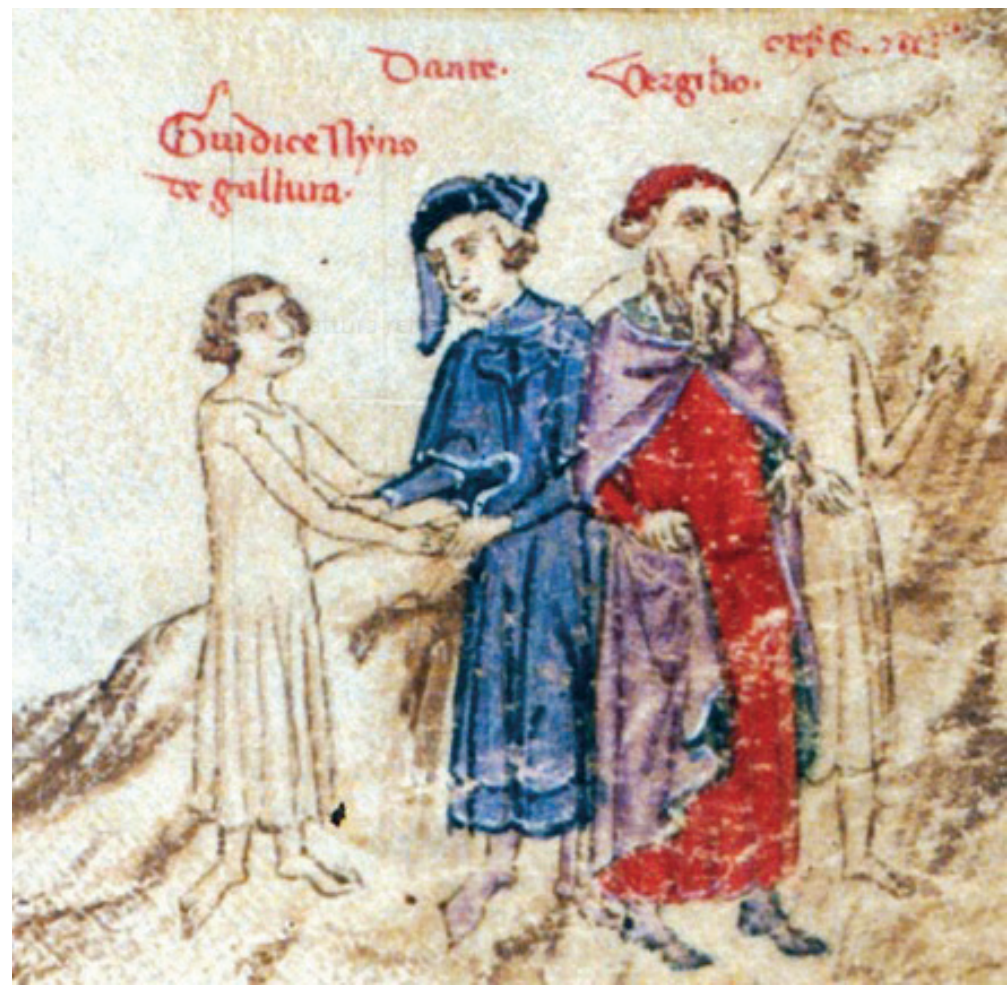

Figure 5. "Dante talks to Nino" (Purg. 8.53), Divine Comedy, Dante Alighieri, I 4C, third quarter, Bodleian Library MS. Holkham misc. 48 p. O7I, Photo: Bodleian Libraries, University of Oxford, 2020.

banished from the city, flesh and blood be damned. And yet no harm ever came to Nino, other than being exiled, which makes me suspect there may have been other reasons. Nino moreover never held a grudge against his uncle, "whom he tried unsuccessfully to rescue after his downfall." ${ }^{16}$ As nefarious as Ugolino's long list of crimes may be, they hardly invite the level of torment Dante prescribes. What crime, then, could justify his placement in hell?

If Dante was ambiguous about the way he describes the Count's crimes, his defense is that: 
ché non è impresa da pigliare a gabbo descriver fondo a tutto l' universe né da lingua che chiami mamma e babbo.

(Inf. 32.7-9)

... it is no easy undertaking, I say, to describe the bottom of the Universe; nor is it for tongues that only babble child's play.

(Ciardi 249)

This language of ineffability can be traced back to the Sybil's speech in Virgil's Aeneid, when she guided Aeneas through the Underworld: ${ }^{17}$

non, mihi si linguae centum sint oraque centum, ferrea vox, omnis scelerum comprendere formas, omnia poenarum percurrere nomina possim.

(Aen. 6.625-27)

A hundred and mouths, a voice of iron, Would not allow me to describe the crimes In all their forms, or list the punishments.

(Ruden I35)

And she would be the one to know. In her youth, the Sybil had once scooped up some sand to ask Apollo if he'd grant her as many years as the number of grains she held. A millennium of living had made her a connoisseur of sin and by extension, the only one qualified to guide the hero into the afterlife.

To go any further, we're going to have to revisit the Graeco-Roman tours of Hell because there is a genealogy of ideas embedded within Dante's epic poem. It was no coincidence that Dante chose Virgil to be his guide in the Inferno; after all, Virgil had landscaped it. Building on what Homer had constructed of Hades in the Odyssey, Virgil fleshed out the Kingdom of the Dead, adding an ethical component that reflected his rigorous study of and devotion to philosophy.

One instance of how philosophy prompted Virgil to deviate from Homer is the prototype of Limbo he invented, 
where dead infants are laid to rest alongside those falsely accused. Though Virgil never names him, one imagines Socrates there. The trial and the death of Socrates is to philosophy what Christ is to Christianity, a martyr who was wrongfully accused and executed by the State. Virgil revolutionized the way we think of hell by showing that our descent is governed by a moral philosophy. When ethics is applied to the afterworld, we see that the tragedy of those falsely accused are as moving as babes robbed of their first breaths. What's crucial for our investigation of Ugolino is how these principles refashion the bottom pit of hell. In Hades, the deepest abyss is called Tartarus, where those who lived wicked lives pay for their crimes with eternal punishments. As the figure of Satan had not yet been imagined, the most loathsome figures at Homer's disposal were Prometheus, Tantalus, and Sisyphus. While all hoisted their treachery upon the very gods themselves, Sisyphus was singled out for the ingenuity of his crime and sentenced to the worst punishment the Gods could conceive: perpetual boredom. What awaited him was a rock divinely ordained to return as quickly as he could roll it up that infernal mountain of damnation, a labor so utterly dull and pointless that a clever man would be driven mad; its cruelty was the point.

Given the moral defects to which the human mind is inclined, Virgil could see that the bottom pit of hell necessitated expansion and duly introduces to this familiar cast of tormented faces a new set of traitors:

... Phlegyasque miserrimus omnis admonet et magna testatur voce per umbras: 'discite iustitiam moniti et non temnere divos.' vendidit hic auro patriam dominumque potentem imposuit; fixit leges pretio atque refixit; hic thalamum invasit natae vetitosque hymenaeos ausi omnes immane nefas ausoque potiti.

(Aen. 6.6I 8-24) 
I DANTE'S CANNIBAL COUNT

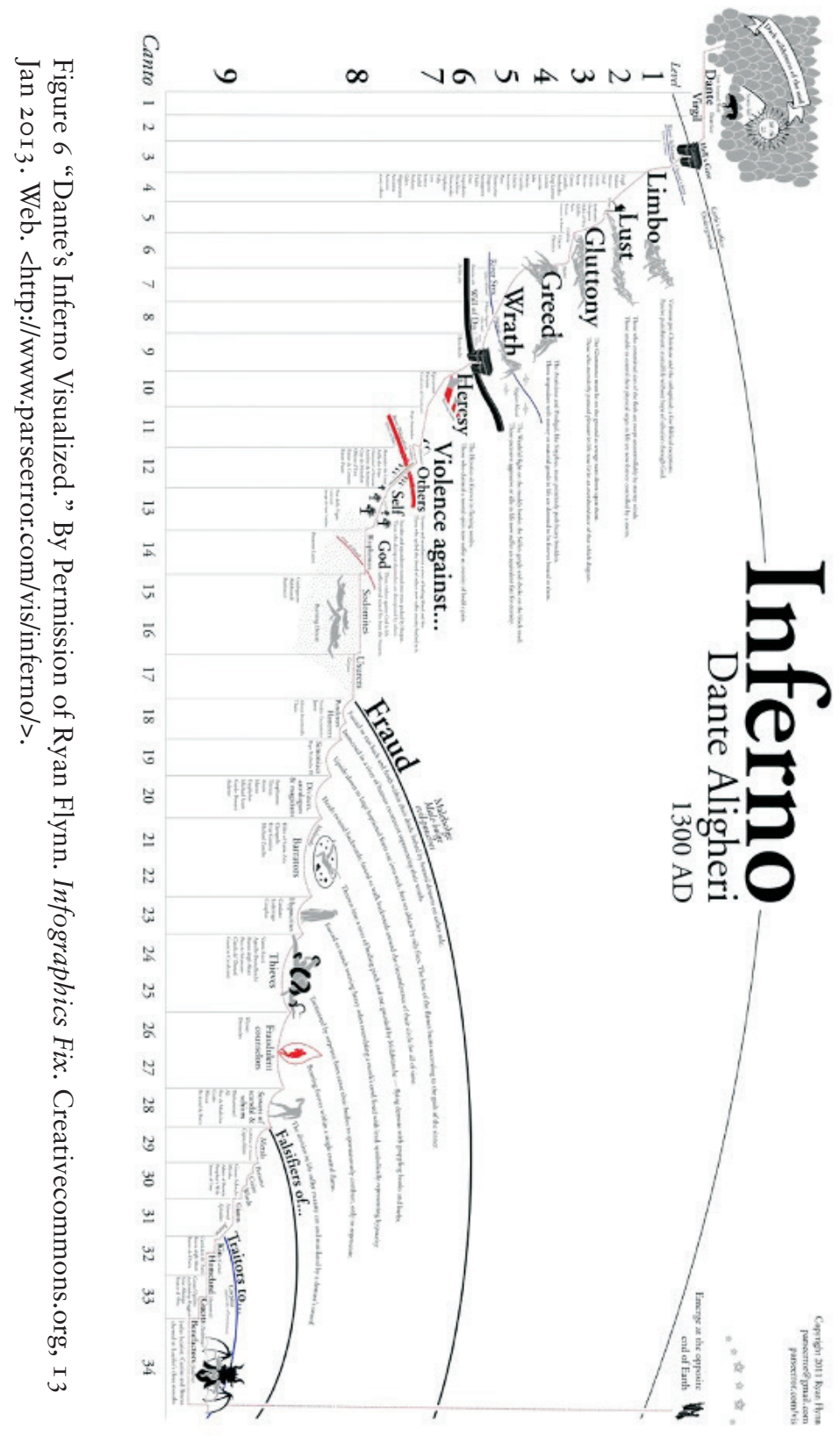


Phlegyas in his torture shrieks a warning

To everyone-his voice rings through the shadows:

"Learn justice from my fate-and fear the gods."

One sold his country and imposed a tyrant;

One, for a price, made laws and remade them.

One stormed his daughter's room-a lawless marriage.

All of them dared great evil and succeeded.

(Ruden I 35)

Clearly Dante was paying attention because he adopted the ranking Virgil devised for those consigned to the depths of Tartarus when he populated the Malebolge with these treacherous souls, whom he says the world would have been better off had they "mei foste state qui pecore o zebe!" ("lived as sheep or goats!"; Inf. 32.I 5; Musa 363). One of the worst, however, is noticeably absent from the roster: the father with a proclivity for incest is nowhere to be found in the Inferno of Dante (fig. 6).

Did Dante dismiss this unholy union as the father's inability to control his lustful appetites? A mindless crime of the body that receives the most lenient of punishments in hell? Would such a sinner have been assigned to Circle 2, alongside Semiramis who married her son? The answer is a resounding no. Any quick study of Semiramis will reveal that she married her son, not out of lust, but out of a rather inordinate desire to seize power and rule as monarch.

The closest match we can find is Myrrha who, like Lot's daughters, seduced her father and for her duplicity is relegated to the tenth bolgia in the eighth circle in Canto 30 , along with other Falsifiers. In both tales, incest occurs only because the fathers are plied with wine and know not what they do. And yet it's not lust that drives Lot's daughters (Genesis I9:3I-36) but rather reproductive necessity: "in this way," the elder tells the younger, we "preserve the family through our father." 18 What drives Myrrha is a mystery, for as Ovid tells it, Cupid denies any involvement: "Ipse negat nocuisse tibi sua tela Cupido, Myrrha" ("he says his arrow did not strike you; he declares his torches innocent"; Metamorphoses I0.3 I I; Mandelbaum 338). She has only herself to blame. 
Dante pulls Myrrha out of Ovid's dark tale and drops her into the Malebolge where she sheds her myrtle bark to run full tilt among those whose minds have snapped. Here the pilgrim encounters Hecuba, the Queen of Troy, who after witnessing the cruel death of her children, starts barking like a rabid dog; and darting past, likewise devoid of mind, is Myrrha, likened to the animal that most suits her: "l porco quando del porcil si schiude" ("like pigs, directionless, broken from their pen"; Inf. 30.27; Musa 344). Unsure if he's awake or dreaming, Dante leaves the circle speechless, "tal mi fec'io, non possendo parlare" ("I found myself: unable to speak"; Inf. 30.I39; Musa 347).

What's unsettling about Myrrha is that she isn't even punished for incest but for her deceit. The real question is which circle of hell would the incest predator be banished to if the one initiating it isn't the offspring, but the begetter, the one who ought to know better? Which makes a difference in hell; as a rule, the more you know, the further you fall. Not all hope is lost. Dante left his readers clues littered throughout Canto 33. The most conspicuous one, for anyone familiar with Hell's prologue, is the appearance of the wolf in Ugolino's "'l mal sonno" ("evil dream"), where he sees himself and his sons being hunted down by the archbishop of Pisa (Inf. 33.26; Musa 37I). What's strange about this dream-or rather nightmare-is that Ugolino and his sons, not his pursuers, appear in the guise of "il lupo e i lupicini" ("the wolf and the wolf cubs"; 29; Musa 37I). Since Ugolino's nightmare is a poetic construction carefully crafted by Dante, the images he conjures up are more intentional than those that might have surfaced from a repressed emotion. What no one seems to be asking is why Dante would deliberately portray the Count as a wolf being hunted down by a pack of dogs?

Symbols are sometimes difficult to decipher, but the wolf isn't one of them: the wolf is the embodiment of evil. In Plato's Republic, Socrates explains that a tyrant is like a sheepdog that out of hunger, or for some other reason, starts at- 


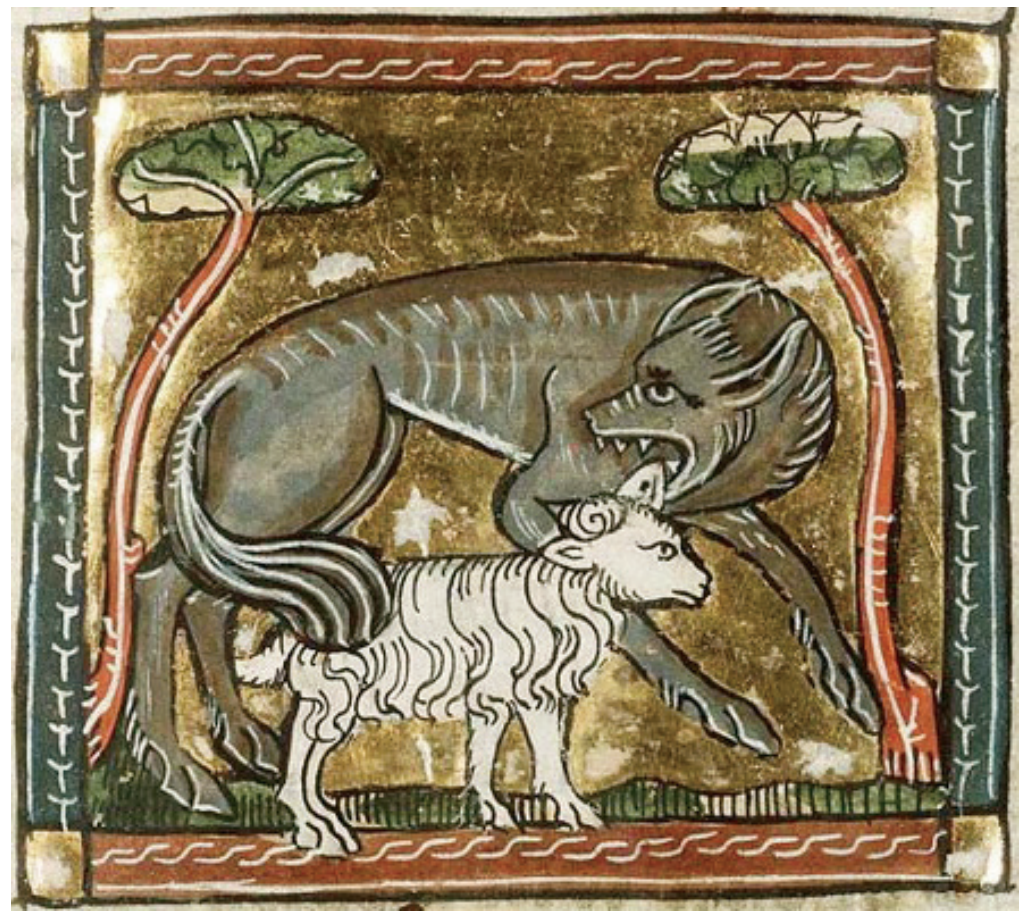

Figure 7. "Wolf Attacks a Sheep." Jacob van Maerlant, Der naturen bloe$m e$; Utrecht, c. I340-1 350 . The Hague, KB, national library of the Netherlands, KA I6, Folio 62r. Accessed June 29, 2020. https://galerij.kb.nl/kb.ht$\mathrm{ml} / \mathrm{nl} /$ dernaturenbloeme/page/63/).

tacking the flock he was supposed to protect (4I6a; fig. 7).

Socrates then applies the same logic to how we develop our character and looks to the soul as the shepherd of our appetites, which like dogs, have to be trained to heel or they revert to their savage natures and become wolves $(565 \mathrm{e})$. Such is the basis for the tale in Ovid's Metamorphoses, where a tyrant named Lycaon served Jupiter a meal of cooked human flesh; the outraged god transformed his inhospitable host into a wolf, an evident judgment on his character:

solitaeque cupidine caedis conligit os rabiem, solitaeque cupidine caedis 
vertitur in pecudes et nunc quoque sanguine gaudet.

In villos abeunt vestes, in crura lacerti:

fit lupus et veteris servat vestigia formae.

(Met. I.234-38)

... as he was always keen on slaughter, now

he turns against the sheep; indeed he's pleased

to shed more blood. His clothes are changed to fur,

his arms to legs: he has become a wolf.

(Mandelbaum I 2)

Aside from Ovid, Dante drew from his teacher Brunetto Latini who wrote a bestiary that references both Plato and Isidore de Seville, and in whose Etymologice I 2.2.23-24 Dante could have learned that the Latin name for wolf, lupus, was derived from the Greek lykos, signaling its "raging rapacity." ${ }^{19}$ From there it was a small leap for "the Wolf [to be] pictured as voraciously insatiable" in Dante's hereafter: ${ }^{20}$

Maledetta sie tu, antica lupa, che più che tutte l'altre bestie hai preda per la tua fame sanza fine cupa!

(Purg. 20.10-I2)

God damn you, ageless She-Wolf, you whose greed, whose never-sated appetite, has claimed more victims than all other beasts of prey!

(Musa 2I4)

The wolf was but one of three beasts that Dante used as his visual icons of sin. Aside from the wolf, which stood for incontinence, there was a lion that represented violence and a leopard that embodied fraud. Why Dante conjures up the image of a wolf in the lowest region of hell where one would expect to see a spotted leopard is perplexing, but we should see it as a flag that's being sent up to alert us that fraud is running amok in the background.

By associating Ugolino with the wolf, we infer something about the character of the Count: he has an appetite he cannot control. As Mark Musa explains in a footnote: 
With this tercet, the Poet recalls to his reader's mind the SheWolf of the opening canto of the Inferno, the beast that blocked the pilgrim's way up that other mountain in the prologue scene to the Divine Comedy. The reader is also reminded of the avaricious Plutus, who guards over the Miserly and Prodigal in Hell . . . All are closely associated with the sins of Incontinence. ${ }^{21}$

While incontinence connotes lust, we can lust for things beyond the flesh. If it is food we're after, we're gluttons, if it is money we are chasing, we're greedy, and as we have seen with Semiramis, we can lust for power, too. So how do we narrow down which of these sins is hidden in his accusation?

We can start by ripping away the veil shrouding Ugolino's nightmare. As you will recall, the Count dreamt he was being hunted down by a "maestro e donno ... Con cagne magre, studiose e conte" ("lord and huntsmen ... with skinny bitches"; Inf. 33. 3 I; Musa 37I). As he and his sons are worn down by chase, Ugolino sees "e con l'agute scane / mi parea lor veder fender li finachi" (long fangs sunk deep into their sides, ripped open"; 35-36; Musa 37I). We are led to assume that it was the dogs that attacked the cubs, his sons. What's curious about this passage is that only the cubs are ripped apart; he says nothing of feeling the sharp fangs himself. When the dust settles, we're told a veil has been removed: "' $l$ mal sonno / che del futuro mi squarciò il velame" ("the evil dream ripped away the veil. ..."; 26-27; Musa 37I).

What was the veil of allegory hiding? ${ }^{22}$ Hidden behind the Count's confession is a graver sin, "però quel che non poui aver inteso" ("what you could not have known"), "fu cruda" ("inhuman circumstances"; Inf. 33.19-20; Musa 37I). Despite the difficulty in deciphering these insinuations, we know that its cruelty arises from a betrayal of trust, for he says "fidandome di lui lo fossi preso ("trusting in him I was made prisoner"; Inf. 33.I7; Longfellow I 83). Law professor Paul G. Chevigny reminds us that, while we tend to think crimes of violence as meriting greater punishment, for Dante, betrayal was worse: "He conceived such crimes to be the 
most deliberate and to do the most damage to the social fabric." 23

We know that Ugolino is guilty of treachery because of his placement on the map, but we recoil so quickly from his alleged cannibalism that we never stop to think that it might be a metaphor. We never really read beyond the literal words, even though Dante advocated this in a letter to his patron Can Grande:

... the sense of this work is not simple, but on the contrary it may be called polysemous, that is to say, 'of more senses than one'; for it is one sense which we get through the letter, and another which we get through the thing the letter signifies; and the first is called literal, but the second allegorical or mystic. ${ }^{24}$

In one sense, we get that Ugolino practiced survival cannibalism, in another we infer that it's similar to cannibalizing your children. What could that be? Is it possible that Dante camouflaged a pedophile in the figure of a cannibal? Incest, too, is implied, "lo padre e figli" ("the father with his sons"; Inf. 33.34; Musa 37I). I can imagine Dante reprimanding the Count by throwing his own words back at him, "Ben se" crudel, se tu già non ti duoli" ("How cruel you are! ... - - do you ever weep?"; 40; Musa 37I) It is a rhetorical question. We know that the Count is incapable of such emotion, for he tells us, in possibly the most well-known line from the canto: "Io non piangeva, si dentro impetrai" ("I did not weep, I turned to stone inside"; 49; Musa 372).

The infamous line is drawn from the tragedy of Medea by Euripides. ${ }^{25}$ As Media kills her sons, first one and then the other cries out for succor, prompting the chorus to cry out:

CHORUs. "Wretched woman, made of stone [emphasis added], made of iron!

I see you really have it in you

to turn your deadly hand

against the boys you bore yourself." 26 
The line removes all doubt as to whether or not Ugolino ate his children, regardless of how appetizing the idea of keeping the audience in suspense might be. What's more, it solves the mystery of where Medea would fall if Dante were to sentence her, given that the question does arise after seeing how Jason is relegated to Circle Eight for seducing and deceiving her. While Euripides may have absolved her, Dante doesn't; she's here in Caina with Ugolino as her proxy for betraying the sacred bonds of love and trust that she owed her boys as their mother.

Another piece of the puzzle comes from Dante's portrayal of Ugolino's sons as young and innocent, a detail that has befuddled scholars. Musa addresses this discrepancy by noting that "in mentioning their 'newborn years,' Dante departs from historical fact, all reports suggest they were grown men, except Anselmuccio, who was fifteen at the time."27

Count Ugolino's real betrayal was against his children, who in their newborn years were "studiose e conte" "well-trained and obedient," and as a consequence made prisoners by their father in whom they trusted (Inf.33.3 I: Musa 37I). Consider for a moment that this is the only canto where we see children suffering: "pianger senti' fra il sonno i miei figliuoli" ("I heard my children sobbing in their sleep"), Ugolino stonily remarks. (38: Musa 37I) The great irony of his children asking for bread is that they will become the bread of his eternal banquet (think of how we first met him). And this irony is only deepened when the children offer themselves up as sacrifices, for as Marianne Shapiro noted, it's "a demonic parody of the Eucharist." ${ }^{28}$ Christ is supposed to be the bread of life but Ugolino fails to understand it spiritually and pursues it carnally. If the Eucharist, as Ronald Herzman argues, represents the spiritual liberation from the bondage of $\sin$ in much the same way that Passover "is a recreation of the liberation of the chosen people from darkness to light, from bondage to freedom," then it follows that a hellish inversion would be a "journey from light to darkness, from freedom to bondage." 29 If the one who "guardai nel viso a' mie' figliuoi sanza far 


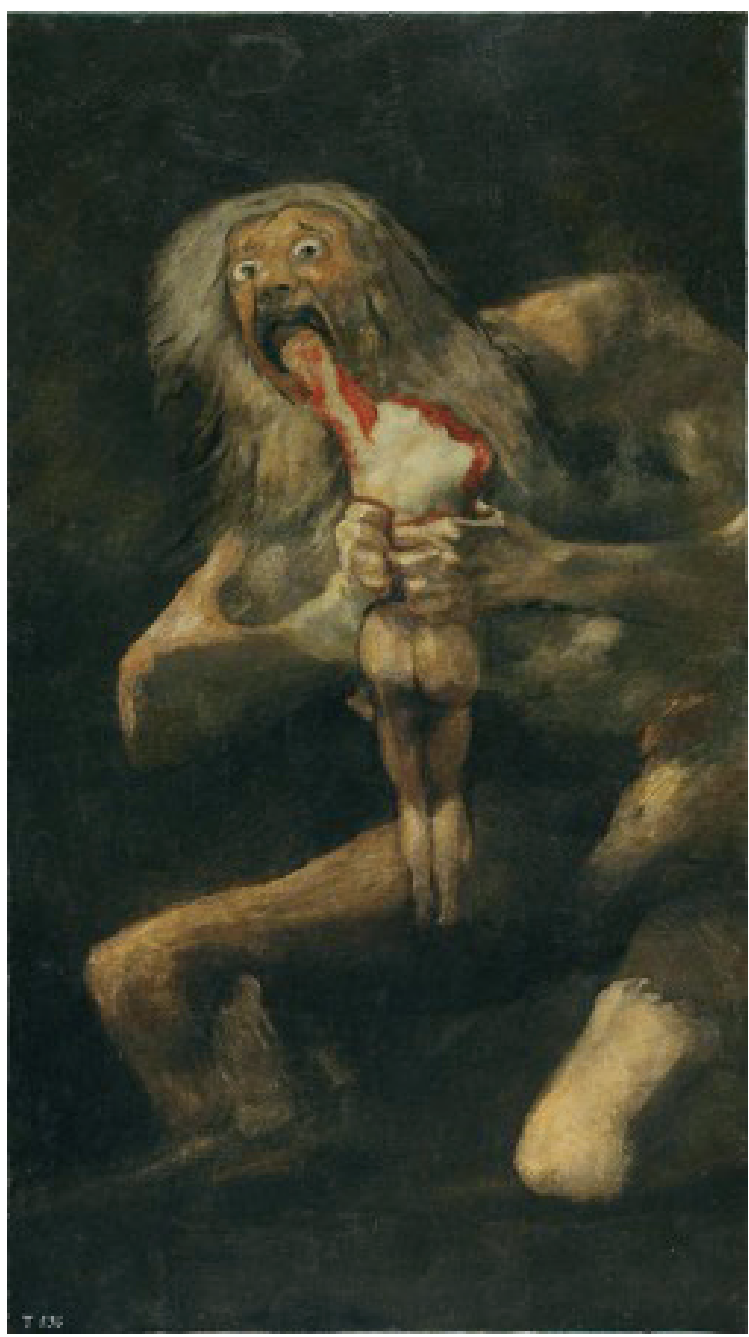

Figure 8. "Saturn" by Goya, I8 I9-23, oil on canvas, (C) Museo Nacional del Prado Museo del Prado. motto" ("stared at my sons' faces without a word") is guarding the prison door, then the Count's sons have been imprisoned in more senses than one (48; Ciardi 258). We can easily deduce what his sons feared was a slow and inexorable death because they tell him they'd suffer less "if you ate us": . . Padre, assai ci fia men doglia / se tu mangi di noi" ("Father, it would give us much less pain / if you ate us" (6I-62; Ciardi 258).

What this plea, performed as a chorus, underscores is that suffering is restricted to the living. Not all torturers murder their victims. As his sons beg to be taken out of their misery, Ugolino responds with a stony silence. This emphasis that Dante places on the Count's silence did not go unnoticed, for Yowell tallied it up: "In the space of 
26 lines, there were 6 references to Ugolino's silence” (I 29). Count Ugolino is a grotesque parody of the benevolent father, like the child-eating Saturn after whom he was surely modeled. Fearful that his offspring would one day overthrow him, Saturn found eating them as soon as they were born a palatable solution (fig. 8). Despite his cunning, the Olympians mounted a revolt and "the child-eater" was banished in perpetuity to the depths of Tartarus.

Another detail, small but significant, is that Dante invokes a comparison to Thebes. While most literary guides overlook it, DiPietro in a lecture for Brown University made the connection that as "an ancient city of serious crimes and murders" Dante was saying "This hell is a new Thebes." ${ }^{30}$ Not to split hairs, but the specific crimes and murders for which the city of Thebes is known are not vague, they lie at the feet of world-famous Oedipus, who killed his father and married his mother-it's a direct allusion to incest.

When we look at how the Count is depicted during those final days behind that locked door in the Muda tower, the evidence against him continues to mount: "già cieco, a brancolar soura ciascuno" " "by then gone blind, groped over their dead bodies"; 73; Musa 372). Regardless of which translation one chooses, the two words that keep resurfacing are blindness and groping. Mandelbaum ${ }^{31}$ translates this line as "now blind, I started groping over each," while Musa ${ }^{32}$ recasts it as over and done with, "then, gone blind, groped over their dead bodies." By placing "already" before "going blind," Pinsky ${ }^{33}$ signals that blindness is being used figuratively here, that we're to infer the Count has moved beyond the confines of sanity: "poscia, più che il dolor, poté il digiuno" ("Then hunger proved more powerful than grief"), a doleful Ugolino recalls (73; Musa 372).

The other word that arrests the reader is groping. In her footnote for verse 73, Anna M. Chiavacci Leonardi explains the significance of the Italian term for groping: "per l'inedia; non vedendoli più, li cerca a tentoni: brancholar vale 
appunto »toccare qua e là senza vedere»." ${ }^{34}$ No longer able to see his children, the starving Count started "groping around in search of them; more precisely, brancholar, i.e., 'groping around,' suggests he was 'touching here and there without seeing." "35 What's interesting about the verb Dante chose is that its Latin roots suggest Ugolino's outstretched arms resembled "the paws of an animal, specifically one with claws." ${ }^{36}$ It's a haunting reminder of the Count's dream, in

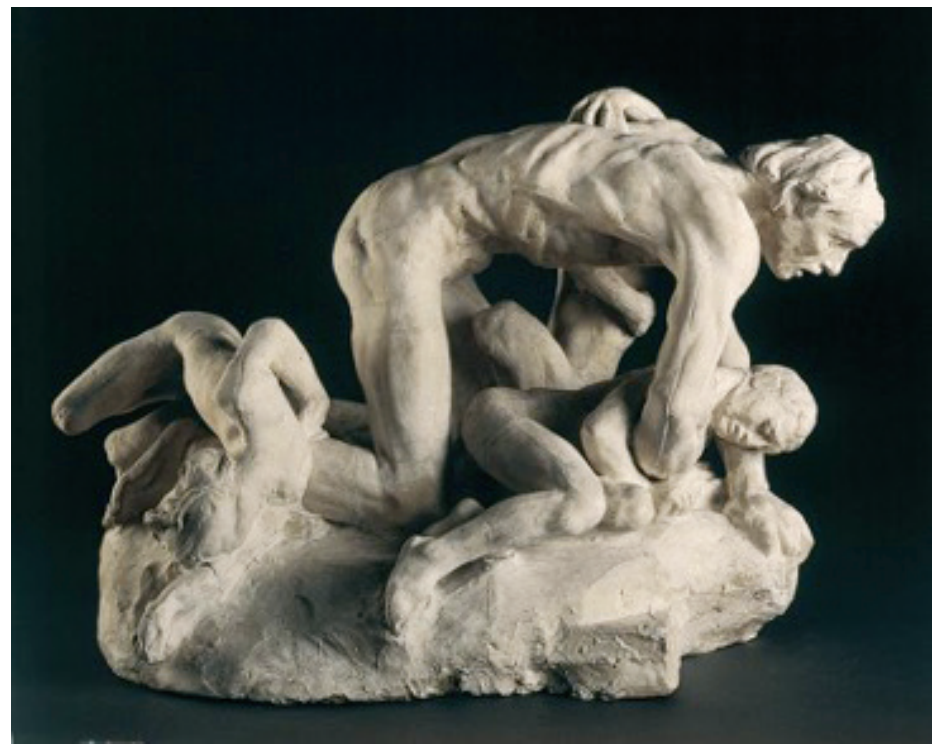

Figure 9. «Ugolin et ses enfants» by Auguste Rodin, Circa I88I, sculpture, Musée Rodin, Paris.

which he saw himself in the guise of a wolf (fig. 9).

"Ambo le man per lo dolor mi morsi" ("I bit my hands in anguish"), the Count admits, but then explains that his sons were mistaken for thinking "ch'io 'l fessi per voglia / di minicar" ("that hunger made me bite my hands"; 58-59; Musa 372). Yowell describes this line as "perversely ironic," but fails to see to what degree. ${ }^{37}$ What pains Ugolino is not grief 
over the tragic fate of his children, but the pangs from an unspeakable appetite for the flesh, an unnatural hunger that blindly devours children in their newborn years.

Dante was wholly justified in banishing Ugolino to Hell's dungeon once we grasp what his moral failing truly is: instead of protecting and nurturing his children, he eroticized them. It is the saddest tale found within The Divine Comedy, as Hollander points out, the episode with Count Ugolino "contains more words for sadness and weeping than any other ... piangre, lagrimare, doglia, dolere, and doloroso occur a total of thirteen times." ${ }^{38}$ One might question why Dante felt a need to conceal a crime that receives universal moral condemnation. Was it a medieval reticence to talk about fornication with children, a concern that a wider application of the allegory might implicate the clergy, a survivor testimony, ${ }^{39}$ a healthy fear of incurring revenge from shaming a powerful family, or was it his reluctance to betray the source of his information? Setting aside some of the more imponderable issues, we can say for certain that it was through his mentor Ser Brunetto ${ }^{40}$ that Dante learned about Ugolino's scandalous imprisonment and it's possible to speculate that Dante may have learnt the details about Ugolino's private life from his contact with Nino Visconti, the Count's nephew, who Dante regarded as a personal friend. It's equally clear that Dante feared retribution, as he was already suffering from exile and poverty. Ultimately, Dante's decision to conceal the truth may have had more to do with the scaffolding of the poem and not the subject of the canto, with his use of allegory within the Commedia that keeps the "truth hidden beneath a lovely fiction" ${ }^{41}$ by default.

What was so innovative about Dante's application is that he dropped the generic avatars of symbolism in favor of "real characters, who, while being themselves, at the same time represented abstract concepts." 42 A perfect illustration of this is maestro Adamo, the counterfeiter Dante interviews in Canto 30 (where Myrrha is seen bolting like a boar). In I 28 I, he 
was burned alive for coining Florins that were three carats shy of the gold standard: "io ebbi, vivo assai di quell ch'i volli, I e ora, lasso, un gocciol d'acqua bramo" (in life I had all that I could desire, / and now, alas, I crave a drop of water"; Inf. 30.62-63; Musa 345). His body is literally shaped by his desire for that drop of water as we're told he looks like a lute: "Io vidi un, fatto a guise di lëuto" ("And there I saw a soul shaped like a lute'; 49). Just as Ugolino substitutes for Saturn, maestro Adamo doubles for Tantalus, the tormented king whose punishment in Hades is a visual symbol of endless frustration: he stands in a pool of water that drops to his ankles as soon as he bends down to slake his thirst; he's also teased by overhanging fruit that's blown out of reach every time he stretches out a hand. Maestro Adamo, racked with perpetual thirst, acts as a human guise for the mythological Tantalus who is himself a human costume for an intangible idea, that of being "tantalized," a word that English derives from his plight. ${ }^{43}$

Thi w lat makes reading Dante's Commedia so rewarding, "the puwer of the form in the interplay of structures and its levels of meaning." ${ }^{44}$ It also means that reading Dante can be a bit of a challenge; like panning for gold in a stream, you have to read his verses carefully to spot the flecks of gold. By persevering, Dante's contribution comes to light. We see how he expanded the circle of the treacherous by adding a betrayal that no one before him had thought to include, one that combined pedophilia with incest. When all the clues hidden in Ugolino's nightmare begin to register-his transformation into a wolf, the youthful depiction of his sons, the chilling plea that they'd suffer less if he ate them, the invocation to Thebes, as well as the etymologically precise verb for groping-the easier it is to see that Ugolino's infernal actions, the cannibalism which he indulges in in sinister silence, are but a thinly veiled metaphor for the sexual abuse he had subjected his sons to. What is the alternative? To believe that Dante branded Ugolino as the worst of all betrayers because 
he failed to console his sons with wise and soothing words in their darkest hour? Or because he gave up a few castles or had a relative expelled from Pisa? To keep things in perspective, there is no pit further down than this, save for the one occupied by Satan himself (fig. Io).

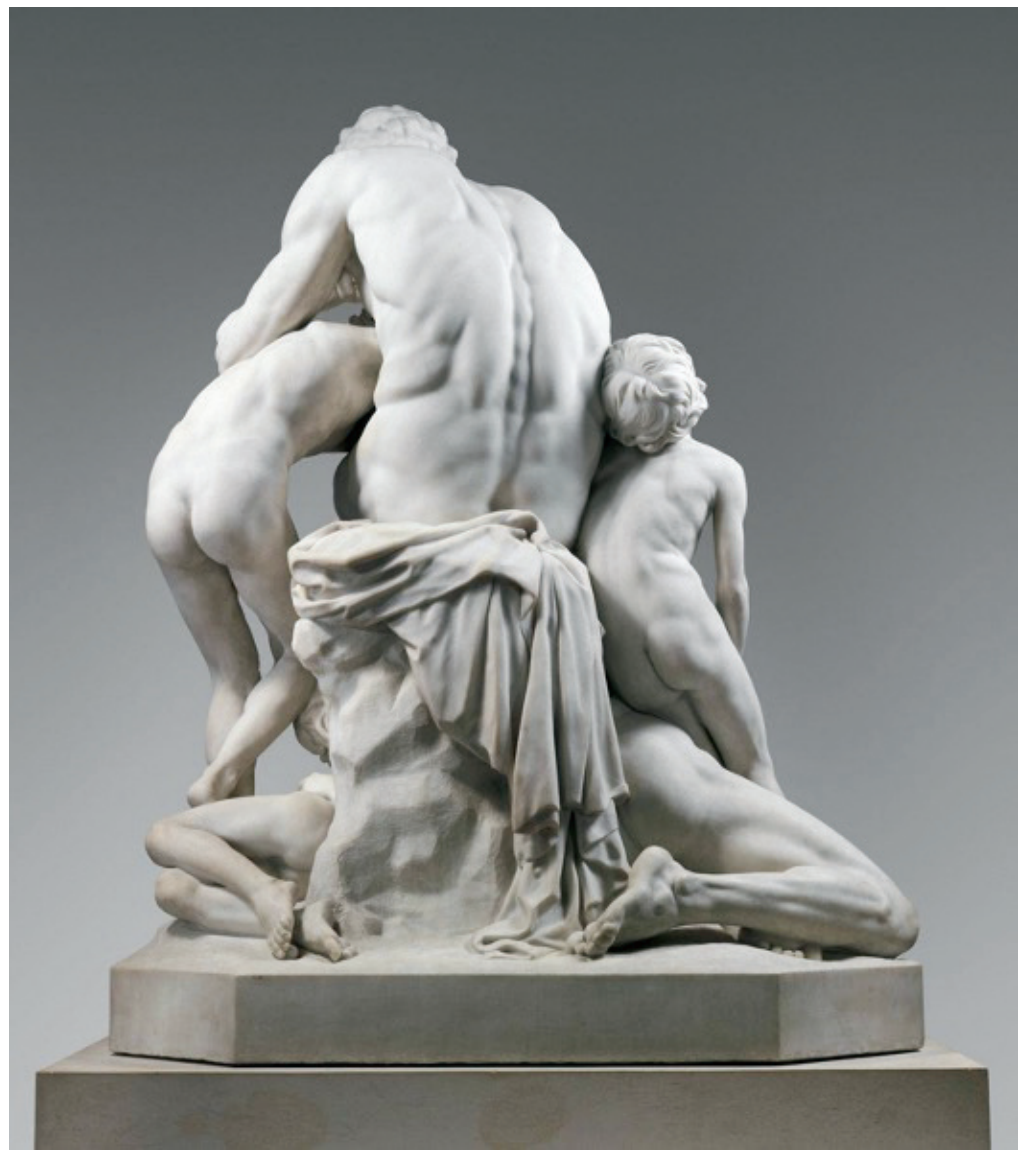

Figure Io. Rear view of "Ugolino and his sons" by Jean-Baptiste Carpeaux. More than illustrating the decisive moment when the cannibal bits his hands in anguish, Carpeaux captures the polysemous nature of Dante's work by offering, from another angle, an alternative reading of the text, one that concurs with my conclusion that Dante was depicting a pedophile. 


\section{NOTES}

All quotations in original verse are from La Divina Commedia di Dante Alighieri (Milan 20I9).

I. Shasta Darlington, "Was Dante Wrong about the Cannibal Count?" The Globe and Mail, April I6, 2018, par. I2.

2. Gloria. "Of Starvation and Cannibalism in Pisa " At Home in Tuscany, blog. October 20, 2016.

3. The Italian Tribune. Graphics, "The Cannibal Who Inspired Dante." April 30, 20I4) par. 6.

4. "Dante And The Cannibal Count." Newsweek. March I3, 20 IO.

5. Note 4 , par. I3.

6. Note 4 .

7. Note 4, par. I4.

8. Prue Shaw, Reading Dante: From Here to Eternity (New York 20I 5 ), Kindle edition.

9. Giuseppe Mazzotta, Reading Dante (New Haven: Yale University Press, 20I4), II3.

Io. Robert Hollander, "Inferno XXXIII, 37-74: Ugolino's Importunity," Speculum 59, no. 3 (I984): 549-55. doi:I0.2307/2846299.) 550.

I I. Donna L. Yowell, "Ugolino's "bestial Segno": The De "vulgari Eloquentia” in Inferno XXXII-XXXIII." (Dante Studies, no. IO4 (I986), I 2 I-43), I 23 .

I2. John Ciardi, trans., The Divine Comedy: The Inferno, The Purgatorio, and The Paradiso (New York 2003), 262.

I3. Teodolinda Barolini, "Inferno Canto 33." Digital Dante, 2018, par. Io. https://digitaldante.columbia.edu/dante/divine-comedy/inferno/inferno-33/.

I4. Note I3, par. I 5

I5. Note I3, par. 6

I6. As quoted by Barolini, note I3, par. I3.

I7. Virgil, Aeneid Book VI [bilingual text], trans. by Seamus Heaney (New York 20I6), 64.

I 8. The Oxford Study Bible (Oxford I992) OT note 28, I9.30-38: "The origin of the Moabites and Ammonites. The previous episode leads to this story of the unflattering origin of the two traditional enemies of Israel."

I9. Robert Lansing, "The Three Beasts," The Dante Encyclopedia (New York 2000) 87 .

20. Charles T. Davis, “Dante's Vision of History,” Dante Studies, no. I I 8 (2000), 246 (http://www.jstor.org/stable/40I6656I).

2. Mark Musa, The Portable Dante (New York 2003), 2 I9.

22. Dante Alighieri, Convivio (The Banquet). Translated by A. S. Kline, 
(www.poetryintranslation.com 2008), 9.

23. Paul G. Chevigny, "From Betrayal to Violence: Dante's Inferno and the Social Construction of Crime," Law \& Social Inquiry 26, no. 4 (200I), 787 .

24. Dante Alighieri. "Episotlæ X.” The Latin Works of Dante (London I904), 347.

25. Euripides appears in Purgatorio 22.105: "Euripides walks with us ..."

26. Euripides, Medea, translated by Sheila Murnaghan (New York 20I8), 33 .

27. Mark Musa, Inferno by Dante Alighieri (rev. ed., vol. I., New York 2003), 377 .

28. Ronald B. Herzman, "Cannibalism and Communion in Inferno XXXIII.” Dante Studies, no. 98 (I980), 75 n.8.

29. Note 28, 66.

30. Pietro DiPietro, "Lectura Dantis: Inferno XXXIII.” Decameron Web | Society, I987, par. 34. http://www.brown.edu/Departments/Italian_Studies/ LD/numbers/oI/dipietro.html.

3I. Allen Mandelbaum, "Canto 33," I982, Digital Dante, 20I8. https:// digitaldante.columbia.edu/dante/divine-comedy/inferno/inferno-33/.

32. Mark Musa, (note 2I), Inferno, 372.

33. Robert Pinsky, The Inferno of Dante: A New Verse Translation (New York I999) Kindle edition.

34. Anna M. Chiavacci Leonardi, "Footnote 73," Commedia by Dante Alighieri (Bologna 200I), 580.

35. Footnote 73 was translated with the help of Dr. Barbara Bird, text message to author, January 29, 2019.

36. Etymology of the verb brancolar was derived from Laura Marino, text message to author, January 29, 2019.

37. Donna L. Yowell, (note I I), “Ugolino’s 'bestial Segno,'” I 30.

38. Robert Hollander, (note Io), "Ugolino's Importunity” 549.

39. survivor testimony: Line 24 gives me pause “. . . and I'll not be the last to know that place" (i.e., the tower).

40. Julia Bolton Holloway discusses Brunetto's involvement in the Pisan revolt led by the Archbishop Ruggieri after threw Ugolino into prison. Introduction to Il Tesoretto (Abingdon I98I), xvii.

4I. Dante Alighieri (note 22), Convivio 37.

42. Barbara Reynolds, Dante (London and New York 20I3), xiii.

43. “'Tantalizing': The Word's Origin in Greek Myth” Merriam-Webster. com. 2019.

44. John Ciardi (note I2), xi. 
28 DANTE'S CANNIBAL COUNT 